РЕФОРМИ В УКРАЇНІ

УДК 346

DOI https:/ / doi.org/10.32837/yuv.v0i1.1557

\title{
P. Cірко,
}

кандидат юридичних наук, доцент, директор Чернівецького інституту Міжнародного гуманітарного університету

\section{ЩОДО ПИТАННЯ УНІФІКАЦІї ЗАКОНОДАВСТВА УКРАЇНИ, ЩО РЕГУЛЮЄ ТРАНСПОРТНІ ПЕРЕВЕЗЕННЯ, 3 МЕТОЮ ПОКРАЩЕННЯ ПРАКТИКИ ЙОГО ЗАСТОСУВАННЯ}

Глобалізація світової економіки та розширення міжнародного співробітництва, розвиток транспортної галузі, системи транспортного забезпечення сприяють формуванню великих транспортних організацій, і найважливішим фактором економічного розвитку стає інтеграція, здійснювана як на галузевому і регіональному, так і на міжгалузевому, міжрегіональному та міжнародному рівнях. Актуальність зумовлена великим значенням перевезень залізничним транспортом, недосконалістю правового регулювання відносин, пов'язаних із перевезеннями вантажів, багажу, пошти та пасажирів залізничним транспортом, відсутністю сучасних комплексних наукових досліджень із цієї теми. Нині існує необхідність визначення й однозначного розуміння базових понять перевезення транспортом, зокрема перевезення залізничним транспортом. ЦК України та ГК України внесли низку істотних новел у правове регулювання договірних зобов'язань у транспортній галузі, викликаних потребами сучасних реформ. На практиці виникає чимало труднощів у застосуванні положень ЦК і ГК України. Надзвичайну актуальність набуває проблема узгодження норм ЦК України та ГК України.

Теоретичну основу дослідження становлять наукові праці таких нау- ковців, як С.С. Алексєєв, А.Г. Биков, Г.С. Гуревич, О.В. Дзера, А.С. Довгерт, В.А. Єгіазаров, А.Д. Кейлін, Н.С. Ковалевська, В.В. Луць, О.Л. Маковський, Я.I. Рапопорт, А.М. Рубін, Г.П. Савічев, О.М. Садіков, Є.О. Харитонов, М.Є. Ходунов, Я.М. Шевченко, Г.Ф. Шершеневич та ін.

Метою статті $€$ науковий аналіз загальних положень законодавства України з метою визначення особливостей уніфікації законодавчого акта України, що регулює транспортні перевезення з метою покращення цивільної практики застосування відповідного законодавства.

Практика використання джерел транспортного права показала наявність у цій галузі ряду суттєвих недоліків, які стосуються, зокрема, неповного обліку в них змін, що відбуваються у сфері надання транспортних послуг та економічного розвитку транспортної галузі, недоцільного відображення тенденції надання послуг транспортних перевезень на основі підприємницької діяльності, недостатнього забезпечення інтересів окремих сторін договірних відносин - пасажира, відправника, одержувача, захисту їх прав та інтересів, непослідовності в підході до ролі планування при здійсненні транспортних перевезень. 


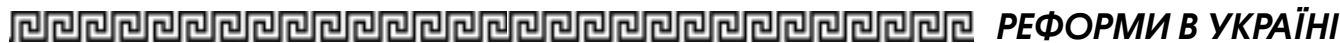

Так, якщо раніше автомобільні, залізничні та внутрішньоводні транспорті статути містили спеціальні розділи, присвячені плануванню перевезень, то нині у більшості транспортних законодавчих актах планування навіть не згадується. Планування й організація перевезення вантажів залишилося регламентованим на законодавчому рівні лише у розділі III Статуту Залізниць України, затвердженому Постановою Кабінету міністрів України від 06 квітня 1998 р. № 457. Однак сьогодні практично залишився механізм правового регулювання, що грунтувався на застарілій ідеології імперативу, а це зумовлює наявність прогалин, неточностей і суперечностей у цивільному праві щодо транспортування залізничним транспортом.

Нині залізничний і автомобільний транспорт займають особливе місце в системі цивільного та господарського комплексу будь-якої країни і є найважливішими сферами суспільного виробництва. Будучи основою поділу праці в суспільстві, залізничний транспорт, як і інший транспорт, здійснює різноманітний зв'язок між промисловістю і сільським господарством країни, між виробництвом і споживанням, між різними економічними районами [11, с. 31].

Виникнення відносин у сфері перевезення сягає давнини. За всіх часів для того, щоб отримати продукцію та різноманітні товари у власність або користування, які виготовляються в іншій місцевості, необхідно було їх перемістити 3 одного пункту в інший. Тому виправданим буде твердження про те, що перевезенням транспортом, зокрема залізничним, $€$ процес переміщення об'єктів матеріального світу з одного місця в інше за допомогою транспортних засобів.

Законодавство у сфері організаціï та здійснення залізничних перевезень, а також транспортної діяльності закріплює загальні правила здійснення перевезень, транспортної діяльності, загальні принципи господарювання у цій сфері, правовий статус тран- спортних організацій і власників вантажу, державних обмежень у сфері транспортної діяльності тощо.

ЦК України не дає визначення поняття перевезення транспортом, а лише посилається на те, що перевезення багажу, пасжирів, пошти, вантажу транспортом здійснюється на підставі договору перевезення (ст. 908 ЦК України). Водночас у ст. 306 ГК Україн міститься визначення поняття «перевезення вантажів», відповідно до чого перевезення вантажів визначається як господарська діяльність, пов'язана 3 переміщенням продукції виробничо-технічного призначення та товарів народного споживання залізницями, автомобільними дорогами, водними та повітряними шляхами, а також транспортування продукції трубопроводами. У Законі України «Про транспорт» також не міститься визначення поняття «перевезення транспортом».

$\mathrm{У}$ юридичній науці термін «перевезення транспортом» означає у загальному понятті «переміщення вантажів, багажу, пасажирів, вантажобагажу та пошти за допомогою транспортного засобу». Фахівці, серед яких слід виділити О.П. Подцерковного [9, с. 261], характеризуючи відносини, пов'язані із транспортним перевезенням вантажів, багажу, пасажирів, пошти, вантажобагажу, відзначають одну головну особливість як галузі матеріального виробництва, яка полягає у наданні специфічних послуг - переміщення вантажів, багажу, пасажирів, пошти, вантажобагажу у просторі. Отже, перевезення здійснюється транспортними засобами, зокрема й залізничними транспортними засобами, на відповідних об'єктах і за їх допомогою.

Процес доставки вантажу 3 місця виготовлення до місця споживання включає виконання великого спектру дій в рамках системи руху вантажу, що визначається як: технічні засоби, комунікації й облаштування всіх видів транспорту; складське господарство; матеріально-технічна база; облаштування транспортно-експедиторських компаній 
для здійснення операцій по угрупованню, комплектації відправлень тощо; матеріально-технічна база лізингових компаній, що надають в оренду контейнери, вагони, пересувні платформи; технічні засоби інформаційно-управлінських систем.

Поряд із цим ця система «охоплює сукупність технологічних, організаційних, правових, соціальних та інших відносин, що виникають у ході транспортного, інформаційного та іншого забезпечення цивільно-господарських зв'язків».

Транспортне забезпечення $€$ структурним складником підприємницької діяльності. На думку О.П. Подцерковного «транспортне забезпечення варто розглядати як систему, що представляє сукупність технічних, технологічних елементів; економічних, комерційно-правових, організаційних впливів; форм і методів управління транспортними операціями та процесами на всіх етапах і рівнях у сфері виробництва, споживання й обігу продукції, що забезпечує суспільне відтворення i раціональне функціонування економіки» [10, с. 315].

Транспортна діяльність не супроводжується створенням нових речей (предметів матеріального світу). Ії цінність в економічному ефекті, який створюється внаслідок переміщення вантажів, багажу, пошти, вантажобагажу, до узгодженого місця. Тому відносини 3 перевезення залізничним транспортом виникають за наявності потреби у територіальному переміщенні вантажів, пасажирів, багажу, пошти за допомогою залізничних транспортних засобів [12, с. 19].

Відповідно до ст. 908 ЦК України, перевезення вантажів, багажу, пасажирів, пошти, здійснюють окремі види транспорту, тобто зокрема залізничний, автомобільний, морський та внутрішній флот, авіаційний, інші види транспорту. Перевезення вантажів здійснюється транспортом, який у всіх своїх різновидах є частиною єдиної транспортної системи України.
Детальна регламентація перевезень транспортом в Україні здійснюється за допомогою відповідних правил перевезень вантажів, пасажирів, пошти, багажу. Транспортне законодавство $є$ найбільш кодифікованою галуззю законодавства, яке враховує правові особливості здійснення перевезень транспортом. Проте в Україні правове регулювання однорідних відносин, пов'язаних із перевезенням транспортом, здійснюється різними нормативно-правовими актами, що мають різну юридичну силу та містять різні положення щодо врегулювання аналогічних умов здійснення перевезень транспортом.

Отже, при неузгодженості транспортного законодавства з ЦК і ГК України виникають спори щодо здійснення перевезення транспортом i неправильного застосування норм законодавства про транспорт.

Формуючи національне законодавство, необхідно враховувати процеси світової економічної інтеграції. Зближення законодавства проводиться на основі принципів рівності сторін, взаємності, неухильного дотримання суверенітету і національних інтересів.

Уніфікація i гармонізація українського законодавства в рамках рекодіфікаціі як складники процесу поступового зближення правових систем повинні мати характер скоординованого, науково обгрунтованого і публічно взаємозбагачуваного, а не механічного запозичення і використання правових норм інших держав.

Так, враховуючи викладене, пропонуємо такі визначення, які можна закріпити на законодавчому рівні при підготуванні законодавчого акта «Транспортного кодексу України»:

1. Перевезення транспортними засобами - здійснення діяльності транспортних організацій та окремих видів транспорту (залізничного, автомобільного, морського, річкового, авіаційного, трубопровідного тощо) щодо переміщення багажу, вантажу, пасажирів, вантажобагажу, пошти, 3 місця від- 


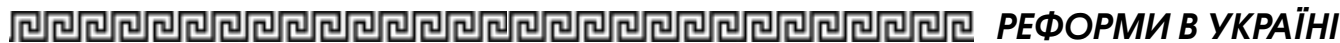

правки до місця призначення залізницями, автомобільними дорогами, водними та повітряними шляхами, а також транспортуванням трубопроводами за договором транпортування, відповідно до якого перевізник зобов'язується перемістити об'єкт перевезення з місця відправки до пункту призначення за певну плату за надання транспортних, перевізних послуг, а замовник транспортного перевезення (відправник, користувач, отримувач) зобов'язується сплатити певну грошову суму за надану послугу перевезення транпортом.

2. Перевезення залізничним транспортом - здійснення діяльності залізницею за договором перевезення щодо переміщення об'єктів транспортування по рейковим шляхам на колісних засобах пересування, які через свої функціональні можливості дозволяють створювати величезні потяги для одночасного переміщення великої кількості об'єктів перевезення (багажу, вантажу, пасажирів, багажовантажу, пошти).

3. Перевезення автомобільним транспортом - здійснення діяльності транспортними організаціями й автоперевізниками за договором перевезення з метою переміщення вантажів, багажу, вантажобагажу, пошти, пасажирів сухопутними транспортними засобами безрейковими шляхами на короткі та великі відстанні від місця відправки до місця призначення.

4. Перевезення морським і річковим транспортом - здійснення діяльності морськими та внутрішньоводними організаціями щодо надання послуг за договором регулярного, нерегулярного, чартерного морського, річкового перевевезння вантажів, багажу, вантажобагажу, пошти, пасажирів сорським і річковим транспортом по водним шляхам між портами відправки та призначення.

5. Перевезення повітряним транспортом - здійснення транспортної діяльності за договором надання послуг регулярного, нерегулярного, чартерного повітряного перевезення багажу, вантажу, пасажирів, пошти повітряним судном по визначеним повітряним маршрутам польотів між погодженими пунктами в повітряному просторі.

Таким чином, прийняття комплексного законодавчого акта, який би регулював діяльність усіх видів транспорту, зокрема «Транспортного кодексу Украіни», призвело б до уніфікації термінологічних визначень, рекодифікації нормативно-правових актів у сфері транспортної та цивільно-господарської діяльності, покращення цивільної практики застосування законодавства, усунення суперечностей і дублювання правових приписів.

Глобалізація світової економіки та розширення міжнародного співробітництва, розвиток транспортної галузі, системи транспортного забезпечення сприяють формуванню великих транспортних організацій, $i$ найважливішим фактором економічного розвитку стає інтеграція, здійснювана як на галузевому $i$ регіональному, так і на міжгалузевому, міжрегіональному та міжнародному рівнях. Актуальність зумовлена великим значенням перевезень залізничним транспортом, недосконалістю правового регулювання відносин, пов'язаних із перевезеннями вантажів, багажу, пошти та пасажирів залізничним транспортом, $i$ відсутністю сучасних комплексних наукових досліджень із цієї теми. Huні існуе необхідність визначення й однозначного розуміння базових понять перевезення транспортом, зокрема залізничним. ЦК України та ГК України внесли низку істотних новел у правове регулювання договірних зобов'язань у транспортній галузі, викликаних потребами сучасних реформ. На практиці виникає чимало труднощів у застосуванні положень ЦК $і$ ГК України. Надзвичайної актуальності набуває проблема узгодження норм ЦК України та ГК України.

Нині залізничний $i$ автомобільний транспорт займають особливе місие в системі ццивільного та господар- 


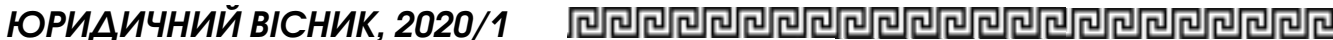

ського комплексу будь-якої країни $i \epsilon$ найважливішими сферами суспільного виробництва. За неузгодженості транспортного законодавства з ЦК та ГК Украӥни виникають спори щодо здійснення перевезення транспортом $i$ неправильного застосування норм законодавства про транспорт.

Формуючи національне законодавство, необхідно враховувати процеси світової економічної інтеграції. Зближення законодавства проводиться на основі приничипів рівності сторін, взаємності, неухильного дотримання суверенітету $i$ національних інтересів. Уніфікаиія i гармонізація українського законодавства в рамках рекодіфікаціi як складники прочесу поступового зближення правових систем повинні мати характер скоординованого, науково обтрунтованого та публічно взаємозбагачуваного, а не механічного запозичення $i$ використання правових норм інших держав.

Таким чином, прийняття комплексного законодавчого акта, який би регулював діяльність усіх видів транспорту, зокрема «Транспортного кодексу України», призвело б до уніфікації термінологічних визначень, рекодифікаиії нормативно-правових актів у сфері транспортноі та цивільно-господарської діяльності, покращення ццивільної практики застосування законодавства, усунення суперечностей $i$ дублювання правових приписів.

Ключові слова: перевезення, залізничний транспорт, відносини з перевезення залізничним транспортом, договір перевезення залізничним транспортом, вантаж, багаж, пасажир.

Sirko R. Concerning the unification of the legislative act of Ukraine regulating transport services in order to improve the civil practice of applying relevant legislation

The globalization of the world economy and the expansion of international cooperation, the development of the transport industry, transport systems, contribute to the formation of large transport organizations, with integration, carried out at the sectoral and regional, as well as at the sectoral, interregional and international levels, becoming the most important factor.The urgency is due to the high importance of rail transport, the lack of legal regulation of relations related to the carriage of goods, luggage, mail and passengers by rail, and the lack of up-to-date comprehensive scientific research on this topic. At present, there is a need to define and unambiguously understand the basic concepts of transportation, in particular, transportation by rail. The Central Committee of Ukraine and the Civil Code of Ukraine have introduced a number of significant innovations in the legal regulation of contractual obligations in the transport sector caused by the needs of modern reforms. In practice, accordingly, there are many difficulties in applying the provisions of the Central Committee and the Civil Code of Ukraine. The problem of harmonization of the norms of the Central Committee of Ukraine and the Civil Code of Ukraine becomes very urgent.

Today, rail and road transport occupy a special place in the system of civil and economic complex of any country and are the most important areas of social production. In case of inconsistency of the transport legislation with the Central Committee and the Civil Code of Ukraine, there are disputes concerning the implementation of transportation by transport and incorrect application of the rules of the legislation on transport.

In shaping national legislation, it is necessary to take into account the processes of world economic integration. The approximation of the laws is done on the basis of the principles of equality of the parties, reciprocity, strict observance of sovereignty and national interests. 
The unification and harmonization of Ukrainian legislation within the framework of recodification as part of the process of gradual approximation of legal systems should have the character of coordinated, scientifically substantiated and publicly enriched development, rather than mechanical borrowing and use of legal norms of other states.

Thus, the adoption of a comprehensive legislative act that would regulate the activity of all modes of transport, in particular, the "Transport Code of Ukraine", would lead to the unification of terminological definitions, the revision of legal acts in the field of transport and civil-economic activity, improvement of the civil practice of law enforcement, eliminating contradictions, and duplicating legal regulations.

Key words: transportation, rail transportation, recodification, rail transportation relations, rail charter, rail transportation contract, contractual liability, obligations, rail.

\section{Література}

1. Конституція України : Закон України від 28 червня 1996 р. Відомості Верховної Ради. 1996. № 30. Cm. 141.

2. Про транспорт : Закон України від 10 листопада 1994 р. із змінами внесеними Законом від 21 грудня 2000 р. Відомості Верховної Ради. 2001. № 9. Сm. 68.

3. Про залізничний транспорт: Закон України від 04 липня 1996 р. № 40. URL: https: / / zakon.rada.gov.ua/laws / show $/ 273 / 96-\%$ D0\% B2\% D1\%80 (Jama звернення: 16.01.2020).

4. Цивільний Кодекс України : Закон України від 16 січня 2003 р. № 40-44.
URL: https://zakon.rada.gov.ua/laws / show/435-15 (дата звернення: 16.01.2020).

5. Статут залізниць України : Постанова Кабінету Міністрів України від 06 квітня 1998 р. № 457. URL: https:// zakon.rada.gov.ua/laws / show / 457-98\% D0\% BF (дата звернення: 18.01.2020).

6. Правила планування перевезень вантажів затвердженні наказом Міністерства транспорту України від 09 грудня 2002 p. № 873, Зареєстровано в Міністерстві юстииіі України 29 грудня 2002 р. за № $1030 / 7318$ із змінами $і$ доповненнями внесеними наказом Міністерства транспорту України від 01 грудня 2008 р. № 1454.

7. Булгакова I.В., Клепкова О.В. Транспортне право України: Академічний курс. Київ : Видавничий дім IнЮре, 2005. 535 с.

8. Господарський кодекс України. Науково-практичний коментар / за ред. В.М. Коссака. Київ : Алерта ; КН ; ЦУЛ, 2010. 672 c.

9. Господарське право : підручник / О.П. Подиерковний, О.О. Квасніцька, А.В. Смітюх та ін. ; за ред. О.П. Подиерковного. Харків : Одіссей, 2010. С. 261-264.

10. Господарське право : підручник / О.П. Подиерковний, В.Г. Олюха, О.О. Квасніцька та ін. ; за ред. О.П. Подцерковного. Одеса: Фенікс, 2018.612 с.

11. Дзюбенко О.Л. Особливості правового регулювання договорів перевезення. Адвокат. 2012. № 11 (146). С. 31-34.

12. Довженко Є.В. Концептуальні засади кодифікаціі національного законодавства про автомобільний транспорт. Юридичний вісник. 2014. № 1 (30). С. 16-20.

13. Цивільне право України. Загальна частина: підручник / за ред. О.В. Дзери, Н.С Кузнєцової, Р.А. Майданика. Київ : Юрінком Iнтер, 2017. 976 c.

14. Яновищька Г.Б., Кучер В.О. Цивільне право України : підручник : у $2 \mathrm{~m}$. / кол. авторів; за ред. Яновицької Г.Б., Кучера В.О. Львів : "Новий світ-2000.: Юрінком Iнтер, 2018. 872 c. 